\title{
Inducibility of Metallothionein Biosynthesis in Cultured Normal and Menkes Kinky Hair Disease Fibroblasts: Effects of Copper and Cadmium
}

\author{
WAI-YEE CHAN, ADOLFO D. GARNICA, AND OWEN M. RENNERT \\ Department of Pediatrics, Oklahoma Children's Memorial Hospital, Department of Biochemistry and Molecular \\ Biology, University of Oklahoma Health Sciences Center, Oklahoma City, Oklahoma, and Department of Pediatrics, \\ College of Medicine University of Florida, Gaimeswille, Florida, USA
}

\begin{abstract}
Summary
Metallothionein biosynthesis is not induced by extracellular copper in Menkes Kinky hair disease (MKHD) or in normal cultured fibroblasts under the conditions of these experiments. In the presence of copper, MKHD fibroblasts also incorporated less cysteine than did normal fibroblasts. Extracellular cadmium greatly enbanced the aptake of cysteine in loth normal and MKHD cultures. By the technique of polyacrylamide gel electrophoresis, it was demonstrated that metallothionein is induced by cadmium in normal and MKHD-cultured fibroblasts.
\end{abstract}

\section{Speculation}

The abnormality in copper homeostasis of MKHD is not caused by an alteration of inducibility of metallothionein. Further investigation of the structure of metallothionein or other copper carrier proteins may uncover the etiology of MKHD.

Menkes kinky hair disease (MKHD) is an X-linked recessive central nervous system degenerative disorder first described by Menkes et al. in 1962 (22). This disorder is characterized by physical and mental retardation, occurrence of peculiar hair, early death and other symptoms of copper deficiency $(5,22,30)$. In 1973, Danks et al. (II) found the MKHD patients have impaired intestinal copper absorption and thus postulated defective intestinal absorption of copper to be the basic biochemical defect of MKHD. Later, investigation demonstrated that the uptake of copper from the intestinal lumen into the mucosal. cells is not impaired in MKHD patients $(12,13)$. This was confirmed by observations in the model system of cultured MKHD fibroblasts (8) Based on the cultured fibroblasts system and in vivo studies the primary defect of the disease is postulated to be the failure of extracellular transport (efflux) of copper from the cells $(8,13)$.

Evans et al. (16) demonstrated that cadmium and zinc were able to antagonize copper metabolism by displacing copper from the sulfhydryl binding sites of a low molecular weight cysteine rich metalloprotein-metallothionein. Consequently, Evans (15) suggested that metallothionein functions in the transport of metals such as copper and zinc. Mutation in metallothionein will therefore lead to altered copper homeostasis. In 1974, Garnica et al. (18) hypothesized that MKHD is caused by an absence or abnormality of metallothionein resulting in poor copper absorption and utilization.

Metallothionein has been isolated from various sources $(3,4,6$, $23,24,25,29,32,34,35,36$ ). It is a small metalloprotein of molecular weight near 7,000. The native protein contains copper, zinc and cadmium. It has a high sulfur content most of which is accounted for by cysteine (constitute $20-30 \%$ of its amino acid residues) $(6,34)$. Besides intracellular transport, other functions have been suggested for metallothionein. These include the detox- ification of heavy metals, e.g. cadmium and mercury (3, 34), temporary storage of trace metals such as zinc and copper (15) etc. Metallothionein is an inducible protein. It has been demonstrated to be inducible in the livers of rats (29), rabbits (23), mice (24), chickens (36), kidney (29) and intestine (32) of rats by cadmium administration.

Abnormality in the metallothionein system in MKHD may be in its structure or inducibility. A previous report indicated metallothioneins isolated from MKHD liver demonstrate lower copper affinity than normal hepatic metallothioneins (9). The experiments reported in this article examine and compare the induction of metallothionein in MKHD and normal cells by copper and cadmium.

\section{MATERIALS AND METHODS}

Two skin fibroblast cultures were established from biopsies of typical MKHD patients using methods previously described (21). Additional MKHD fibroblast cultures were obtained from the Human Genetic Mutant Cell Repository (GM 220/227, GM 245, GM 1057) (Camden, NJ), and the American Type Culture Collection (ATCC CRL 1230) (Rockville, MD). Control cell cultures were obtained from foreskin or upper arm of normal babies and from the Human Genetic Mutant Cell Repository and the American Type Culture Collection. All the cultures were derived from male infants between the age of 5 days and 6 months.

All the cultures were grown in $12 \mathrm{ml}$ completed media in 75 $\mathrm{cm}^{2}$ plastic culture flasks (Corning, NY) and incubated in a humidified environment of $5 \% \mathrm{CO}_{2}$ at $37^{\circ} \mathrm{C}$. Completed medium consisted of Eagle's minimum essential medium with Hank's balanced salt solution (HBSS; GIBCO, Grand Island, NY) supplemented with $10 \%$ fetal calf serum (ISI, Cary, IL), $1 \%$ antibioticantimycotic solution $(100 \mathrm{U} / \mathrm{ml}$ Penicillin, $250 \mathrm{ng} / \mathrm{ml}$ Fungizone, $100 \mathrm{ng} / \mathrm{ml}$ Streptomycin) (ISI), and adjusted to a $\mathrm{pH}$ of 7.2 with 7.5\% sodium bicarbonate solution (ISI).

Approximately seven days were required for the cells to grow to confluent monolayers. Confluent cultures were subcultured by trypsinization in a 1:3 ratio (19). Medium was changed every three days. Only confluent cultures with a passage number between 6 to 13 were used for experiments.

Radionuclides used included copper-64 ( $\left.{ }^{64} \mathrm{Cu}\right)$, cadmium-109 $\left({ }^{109} \mathrm{Cd}\right)$ and sulfur-35 $\left({ }^{36} \mathrm{~S}\right) .{ }^{64} \mathrm{Cu}$ was purchased from New England Nuclear (Boston, MA) in the form of $>99 \%$ pure ${ }^{64} \mathrm{Cu}\left(\mathrm{NO}_{3}\right)_{2}$ in IN $\mathrm{HNO}_{3+}$ Specific activity of ${ }^{64} \mathrm{Cu}$ was $621 \mu \mathrm{Ci} / \mathrm{mg}$. ${ }^{109} \mathrm{Cd}$ was purchased from Amersham/Searle (Arlington Heights, IL), in the form of carrier free ${ }^{109} \mathrm{CdCl}_{2}$ in $0.1 \mathrm{M} \mathrm{HCl}$. Specific activity of ${ }^{109} \mathrm{Cd}$ was $727 \mu \mathrm{Ci} / \mu \mathrm{g}$. Samples containing ${ }^{64} \mathrm{Cu}$ or ${ }^{109} \mathrm{Cd}$ were counted in polypropylene test-tubes (Packard, Downers Grove, IL) with a Packard Auto-Gamma Counter model 5210.. The counting efficiency for ${ }^{64} \mathrm{Cu}$ was $28 \%$ and ${ }^{10 \%} \mathrm{Cd}$ was $36 \%$. All the counts for ${ }^{64} \mathrm{Cu}$ were corrected for decay. Sterilized L- $\left[{ }^{35} \mathrm{~S}\right]$ cysteine 
hydrochloride was obtained from Amersham/Searle in aqueous solution. The specific activity of $L-\left[{ }^{36} \mathrm{~S}\right]$ cysteine were counted in a Packard Tri-Carb Liquid Scintillation Spectrometer model 3320 after thorough mixing with $10 \mathrm{ml}$ of Aquasol (New England Nuclear) in glass scintillation vials (Wheaton, Millville, NJ). The counting efficiency obtained was $92 \%$.

Electrophoresis was performed in $12.5 \%$ polyacrylamide gel (Sigma, St. Louis, MO), with $0.075 \%$ TEMED (Canalco, Elkhart, IN), and $0.07 \%$ ammonium persulfate (Sigma) according to the procedures described by Swank and Munkers (33) and David (14). Instead of staining after electrophoresis, the gel columns were frozen in dry ice, and were cut into $1 \mathrm{~mm}$ thick slices with a gel slicer (Bio-Rad, Richmond, CA). Gel slices were dissolved by incubating one slice with $0.5 \mathrm{ml}$ of $30 \%$ hydrogen peroxide (Fisher, Pittsburg, PA), at $50^{\circ} \mathrm{C}$ for four hours in a glass vial (39).

Capability of both copper and cadmium to induce the synthesis of metallothionein in both normal and MKHD cultured fibroblasts were examined by incubating the cultures in media containing both ${ }^{64} \mathrm{Cu}$ and $\left.\mathrm{L}--^{35} \mathrm{~S}\right]$ cysteine or ${ }^{109} \mathrm{Cd}$ and $\left.\mathrm{L}-{ }^{35} \mathrm{~S}\right]$ cysteine at $37^{\circ} \mathrm{C}$. The radio active quantities added to $10 \mathrm{ml}$ of medium were $34 \mu \mathrm{Ci}$ for ${ }^{144} \mathrm{Cu}, 4 \mu \mathrm{Ci}$ for ${ }^{109} \mathrm{Cd}$, and $7.5 \mu \mathrm{Ci}$ for $\mathrm{L}$-[ $\left[{ }^{35} \mathrm{~S}\right]$ cysteine which corresponded to concentrations of $5.5 \mu \mathrm{g} / \mathrm{ml}, 5.5 \mathrm{ng} / \mathrm{ml}$ and $0.2 \mathrm{nmole} / \mathrm{ml}$ of copper, cadmium and cysteine, respectively. The amount of ${ }^{64} \mathrm{Cu}$ added to the medium was high because of the. very short half-life (12.9 hours) of the isotope. A higher dose of L$\left[{ }^{35} \mathrm{~S}\right]$ cysteine than ${ }^{109} \mathrm{Cd}$ was used to ensure sufficient incorporated radioactivity into any newly synthesized metallothionein. The characteristic high cysteine content of metallothionein enables the utilization of $\mathrm{L}-\left[{ }^{35} \mathrm{~S}\right]$ cysteine incorporation as an indicator of $d e$ novo metallothionein synthesis (32). The cultures were incubated for $1,3,5,7$ and 10 hour periods at $37^{\circ} \mathrm{C}$. After withdrawing the radioactive medium, the cells were washed twice with $5 \mathrm{ml}$ of calcium-magnesium free phosphate buffered saline and trypsinized. The cells were harvested with $2 \mathrm{ml}$ of distilled water and the flask was rinsed twice with $1.5 \mathrm{ml}$ of water. The $5 \mathrm{ml}$ aqueous cell suspensions were pooled, and the cells lysed by freezing and thawing thrice. Protein content of the cell lysate was determined by the method of Lowry et al. (20). One $\mathrm{ml}$ of the cell lysate was counted for ${ }^{35} \mathrm{~S}$. Another $\mathrm{ml}$ was counted for ${ }^{64} \mathrm{Cu}$ or ${ }^{109} \mathrm{Cd}$. Electrophoresis was done with $0.2 \mathrm{ml}$ of cell lysate. The gel columns after electrophoresis were sliced, first counted for ${ }^{64} \mathrm{Cu}$ or ${ }^{109} \mathrm{Cd}$ and then dissolved and counted for ${ }^{35} \mathrm{~S}$.

\section{RESULTS}

Metallothionein has a very high cysteine content. Thus, the concurrent $\mathrm{L}-\left[{ }^{35} \mathrm{~S}\right]-$ cysteine and metal incorporated radioactivity peak was used as an indication of metal induced metallothionein synthesis (32). Both normal and MKHD cells incorporated added $\left.\mathrm{L}-{ }^{35} \mathrm{~S}\right]$-cysteine in the medium in the absence of exogenously added metal. L- $\left[{ }^{35} \mathrm{~S}\right]-$ cysteine radioactivity incorporated in the first hour of incubation was $(0.41 \pm 0.06) \times 10^{5} \mathrm{cpm} / \mathrm{mg}$ cell protein in MKHD cells compared with $(1.55 \pm 0.05) \times 10^{6} \mathrm{cpm} / \mathrm{mg}$ cell protein in normal cells. MKHD cells continued to incorporate L$\left[{ }^{35} \mathrm{~S}\right]$-cysteine up to the end of the period of study, while normal cells showed peak incorporation at the seventh hour. The percent change of ${ }^{35} \mathrm{~S}$ incorporated as contrasted to the first hour in both normal and MKHD cells was plotted in Figure 1 . The highest incorporated radioactivity in MKHD cells at the tenth hour was $(3.50 \pm 0.10) \times 10^{5} \mathrm{cpm} / \mathrm{mg}$ cell protein $(4.0$ nmole cysteine $/ \mathrm{mg}$ cell protein) while the peak incorporation in normal cultures at the seventh hour was $(5.0 \pm 0.42) \times 10^{5} \mathrm{cpm} / \mathrm{mg}$ cell protein $(5.70$ nmole cysteine/mg cell protein). Thus normal cells appeared to respond to added cysteine faster than MKHD cells.

Inducibility of metallothionein by copper was examined by incubating the culture with medium containing both $L-\left[{ }^{35} \mathrm{~S}\right]-\mathrm{cys}$ teine and ${ }^{64} \mathrm{Cu}$. The average copper concentration of the completed culture media was $48.70 \pm 20.0 \mathrm{ng} / \mathrm{ml}$ as determined by flameless atomic absorption spectrophotometry $(8)$. The big variation was caused by the fluctuation of copper concentration of the fetal calf serum used. The lower limit of the cytotoxicity level of copper to

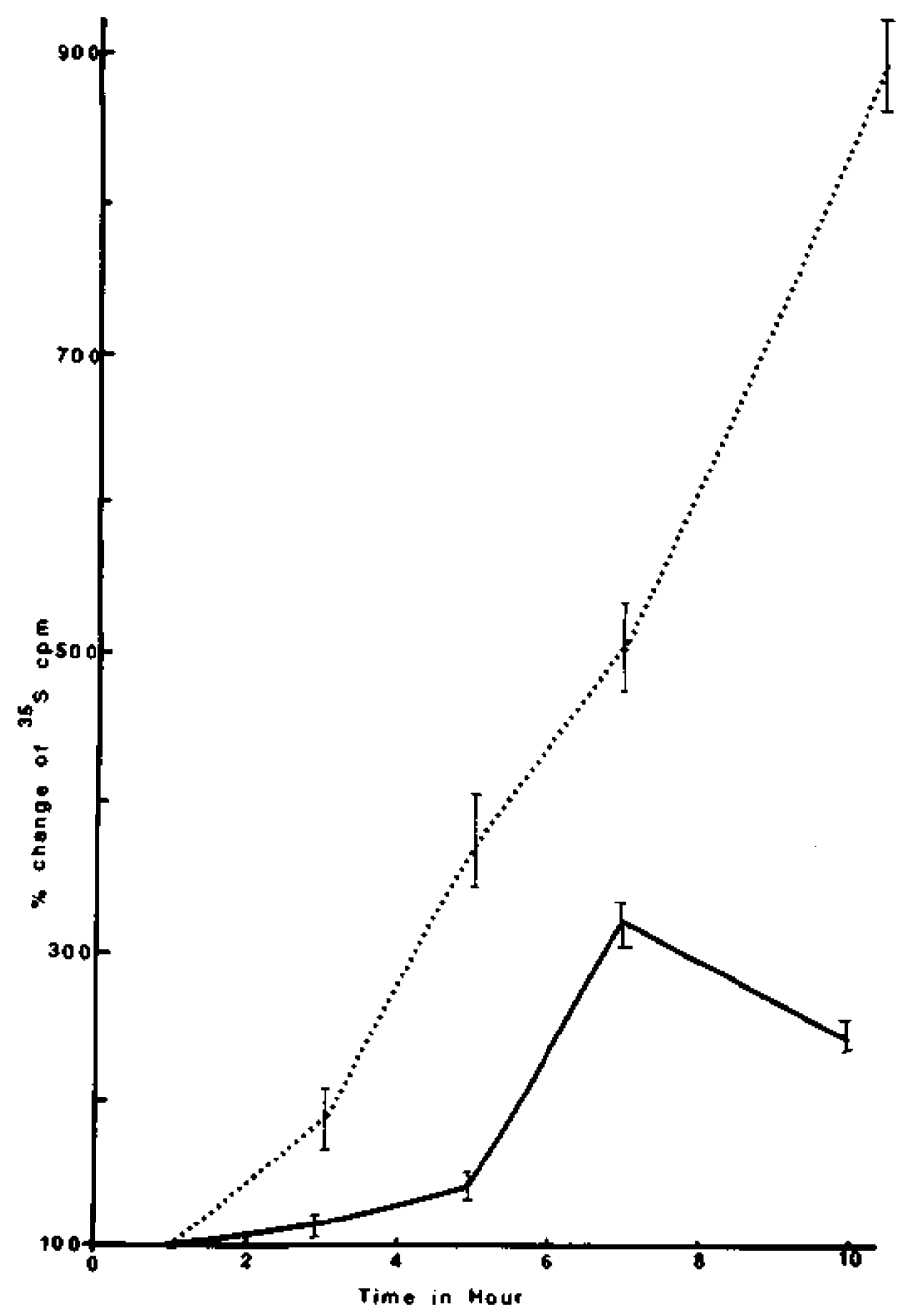

Fig. 1. Incorporation of $\left.\mathrm{L}^{*}{ }^{*} \mathrm{~S}\right]$ cysteine by cultured fibroblasts at $37^{\circ} \mathrm{C}$. Cells were incubated at $37^{\circ} \mathrm{C}$ with medium containing 0.2 nmole $\mathrm{L}-\left[{ }^{36} \mathrm{~S}\right]$ cysteine/ml. They were harvested at $1,3,5,7$, and 10 hour periods, and lysed by freezing and thawing thrice. One $\mathrm{ml}$ of cell lysate was counted for ${ }^{35} \mathrm{~S}$. (For details, see Materials and Methods.) Specific activity of $\mathrm{L}-\left[{ }^{35} \mathrm{~S}\right]$ cysteine is $39.1 \mathrm{mCi} / \mathrm{nmole}$. Radioactivity is expressed as $\mathrm{cpm} / \mathrm{mg}$ cell protein. Results at various time periods are expressed as percent of the first hour incorporation. Values in the Figure are means of 2 different cultures of MKHD and normal fibroblasts. The first hour result for MKHD cells was $(0.41 \pm 0.06) \times 10^{5} \mathrm{cpm} / \mathrm{mg}$ cell protein and for normal cells was $(1.5 \pm 0.05) \times 10^{5} \mathrm{cpm} / \mathrm{mg}$ cell protein. $\cdots .$. MKHD cells. Normal cells.

MKHD fibroblasts was reported to be $15 \mu \mathrm{g} / \mathrm{ml}$ medium, and for normal fibroblasts it was well above $15 \mu \mathrm{g} / \mathrm{ml}$ medium (8). Thus the medium copper concentration used in this study $(5.5 \mu \mathrm{g} / \mathrm{ml}$ medium) was well below the cytotoxicity level of the element for both MKHD and normal fibroblasts. This was also confirmed by observation of normal morphology of both control and MKHD cells at the end of the tenth hour. To show the results more clearly, the percent change of incorporated ${ }^{64} \mathrm{Cu}$ and $\mathrm{L}-\left[^{36} \mathrm{~S}\right\}$-cysteine radioactivity with respect to the first hour incorporation was calculated. The results are presented in Figure 2. Graph $A$ is the induction profile for normal cultures, and graph $B$ is the induction profile for MKHD cultures. From the graph, it is obvious that both normal and MKHD cells showed a distinct $L-\left[{ }^{35} \mathrm{~S}\right]-\mathrm{cysteine}$ incorporation peak. The incorporation pattern of ${ }^{64} \mathrm{Cu}$ is not as clear as that of $\left.\mathrm{L}_{-}{ }^{33} \mathrm{~S}\right\}$-cysteine. Incorporation of ${ }^{84} \mathrm{Cu}$ tended to be still increasing at the end of the study period. However, both normal and MKHD cells exhibited a relative ${ }^{64} \mathrm{Cu}$ incorporation peak at the fifth hour. The ${ }^{64} \mathrm{Cu}$ and $\mathrm{L}-\left[{ }^{35} \mathrm{~S}\right]-$ cysteine peaks coin- 